University of Nebraska - Lincoln

DigitalCommons@University of Nebraska - Lincoln

1-8-1997

\title{
Genetic and Environmental Parameters for Ovulation Rate, Twinning Rate, and Weight Traits in a Cattle Population Selected for Twinning
}

K. E. Gregory

Roman L. Hruska U.S. Meat Animal Research Center, USDA-ARS

G. L. Bennett

Roman L. Hruska U.S. Meat Animal Research Center, USDA-ARS, gary.bennett@ars.usda.gov

L. Dale Van Vleck

University of Nebraska-Lincoln, dvan-vleck1@unl.edu

S. E. Echternkamp

Roman L. Hruska U.S. Meat Animal Research Center, USDA-ARS

Larry V. Cundiff

University of Nebraska-Lincoln, Icundiff2@unl.edu

Follow this and additional works at: https://digitalcommons.unl.edu/animalscifacpub

Part of the Animal Sciences Commons

Gregory, K. E.; Bennett, G. L.; Van Vleck, L. Dale; Echternkamp, S. E.; and Cundiff, Larry V., "Genetic and Environmental Parameters for Ovulation Rate, Twinning Rate, and Weight Traits in a Cattle Population Selected for Twinning" (1997). Faculty Papers and Publications in Animal Science. 267.

https://digitalcommons.unl.edu/animalscifacpub/267

This Article is brought to you for free and open access by the Animal Science Department at DigitalCommons@University of Nebraska - Lincoln. It has been accepted for inclusion in Faculty Papers and Publications in Animal Science by an authorized administrator of DigitalCommons@University of Nebraska - Lincoln. 
Genetic and Environmental Parameters for Ovulation Rate, Twinning Rate, and Weight Traits in a Cattle Population Selected for Twinning, ${ }^{1,2}$

\author{
K. E. Gregory*,3, G. L. Bennett*, L. D. Van Vleck', \\ S. E. Echternkamp*, and L. V. Cundiff*
}

Roman L. Hruska U.S. Meat Animal Research Center, ARS, USDA,

*Clay Center, NE 68933-0166 and tLincoln, NE 68583-0908

\begin{abstract}
A project was implemented in 1981 with the objective of increasing twinning rate in cattle. Daughters of foundation sires had twin calves at a frequency of from 8 to $13 \%$, and foundation females had twin calves at an average frequency of $50 \%$. Data were analyzed on twinning rate, ovulation rate, and weight traits. The $\mathrm{h}^{2}$ of ovulation rate increased from .11 to .38 for a single estrous cycle to the mean of eight estrous cycles. From all data, $h^{2}$ for single observation of ovulation rate and twinning rate were .10 and .09 , respectively. The $r_{\mathrm{g}}$ between them was .75. The $\mathrm{h}^{2}$ of weight traits ranged from .42 to .54 when weight traits were analyzed pair-wise with ovulation rate and with twinning rate. The $r_{g}$ between weight traits with ovulation rate ranged from .15 to .30 and with twinning rate ranged from .24 to .39. Phenotypic mean twinning rate increased from 1.07 to
\end{abstract}

1.29 calves per parturition for females born 1981 through 1993, and adjusted mean predicted breeding value (PBV) increased from 1.07 to 1.33 calves per parturition. Phenotypic mean ovulation rate for fall of 1984 through fall 1994 birth groups increased from 1.11 to 1.26 per estrous cycle, and adjusted mean PBV for ovulation rate increased from 1.11 to 1.29 per estrous cycle. Because of the high $r_{g}$ (i.e., .75) between ovulation rate and twinning rate, and because of a $h^{2}$ of .35 for ovulation rate for the mean of six estrous cycles, repeated records of ovulation rate in puberal heifers is an effective indirect selection criterion for twinning rate. The positive $r_{g}$ between growth traits and ovulation and twinning rate suggest the need for some compromise when the selection goal is increased twinning rate with no increase in growth and size.

Key Words: Cattle, Twinning, Weight, Selection, Genetic Trend

J. Anim. Sci. 1997. 75:1213-1222

\section{Introduction}

Rate of reproduction has a major impact on life cycle costs of production of different animal species and on their competitiveness for different types of production resources. More than $50 \%$ of the feed units used by the beef cattle industry of the United States are needed to meet maintenance requirements of reproducing females. The comparable value in meat chickens is approximately 3\% (Gregory and Dickerson, 1989). High-producing dairy cows produce five

\footnotetext{
${ }^{1}$ Cooperation of the Nebraska Agric. Res. Div., Univ. of Nebraska, Lincoln is acknowledged.

${ }^{2}$ Appreciation is expressed to Gordon Hays, J ohn Stark, Melvin Sukup, Dan O'Keif, Doug Felber, Mike Wilford, Loyal Clang, and Dave Powell for operations support provided to this project; to Darrell Light for data management and analyses; and to Deborah Brown for secretarial support.

${ }^{3}$ To whom correspondence should be addressed.

Received August 2, 1996.

Accepted J anuary 8, 1997.
}

times as much milk protein per unit of feed as beef cattle produce as beef protein (Reid et al., 1980). Results from experimentation and computer simulation suggest that input costs per unit of beef output could be reduced by $24 \%$ in the proportion of a herd that produces twins (Guerra-Martinez et al., 1991). Because of the time and effort required to develop a population with a high twinning frequency, private sector interests are not likely to make the investment required. Thus, the development of a population of cattle with a high twinning rate (i.e., $\geq 40 \%$ ) that is competitive in production and carcass traits is likely to be required for consideration of a twinning technology by the beef cattle industry. A high level of calving difficulty has been reported in this population for twin and single births (Gregory et al., 1996). A high genetic correlation exists between birth weight and calving difficulty score (Gregory et al., 1995a,b). Further, no breed of cattle that is small in size produces twins at a high frequency (Rutledge, 1975). A primary objective of this study was to estimate genetic parameters of weight traits including the 
Table 1. Twinning records of foundation cows and their daughters

\begin{tabular}{|c|c|c|c|}
\hline \multirow[b]{2}{*}{ Item } & \multicolumn{2}{|c|}{ Foundation cows } & \multirow{2}{*}{$\begin{array}{l}\text { Daughters of } \\
\text { foundation cows }\end{array}$} \\
\hline & Before entry & After entry & \\
\hline No. of cows & 307 & 307 & 763 \\
\hline Progeny & 1,348 & 1,194 & 3,570 \\
\hline Progeny/cow & 4.4 & 3.9 & 4.7 \\
\hline Parturitions & 918 & 1,024 & 3,154 \\
\hline Parturition/cow & 3.0 & 3.3 & 4.1 \\
\hline Progeny/parturition & 1.5 & 1.17 & 1.13 \\
\hline Mean calving age, yr & 4.1 & 7.1 & 4.5 \\
\hline
\end{tabular}

genetic correlations between weight traits and ovulation and twinning rate as a basis for developing selection procedures to reduce calving difficulty and achieve optimum growth rate while optimizing selection response for ovulation and twinning rate.

\section{Materials and Methods}

Experimental Population. This effort was implemented as a formal project in 1981. There were 307 foundation females in the project with 96 originating in private sector herds and 211 originating from other projects at the U.S. Meat Animal Research Center (MARC). Twinning records of foundation cows before and after entry into the twinning project and twinning records of their daughters are shown in Table 1. Foundation sires included sons of foundation cows, plus a Charolais sire and a Pinzgauer sire whose daughters produced twins at a high frequency in another project at the Research Center. Also, semen from Swedish Friesian (8), Swedish Red and White (5), and Norwegian Red (2) sires, whose daughters had produced twins at a frequency of from 8 to $13 \%$, was imported and used in the project. Semen was imported in 1983, 1984, 1988, and 1991. Mean breed ancestry of calves born in 1994 and 1995 is given in Table 2. Contributions of the Swedish Red and White and Norwegian Red breeds are combined because their Herd Books are open to each other. Also, contributions by the Hereford and Angus breeds are combined because of the relatively small contribution of each. Frequency distribution of ovulation rate of the 2,849 puberal heifers included in this study is in Table 3. Frequency distribution of number of parturitions and twinning rate for the 2,113 cows included in this study is in Table 4.

Mating Plan. A multiple-trait (i.e., ovulation rate and twinning rate), repeated records animal model was used to predict breeding value for twinning rate. This procedure combined information on individuals and relatives for ovulation and twinning rate and was implemented with selections and matings made in 1990 (Van Vleck et al., 1991a,b). Before implementation of this procedure, selections were based on an estimated breeding value that included information on twinning rate, augmented by independent culling levels for sires based on mean ovulation rate of their daughters.

Approximately 750 cows calving per year have been included in the project since 1991. Calving was both spring and fall. Mating seasons were $70 \mathrm{~d}$. Matings were made to achieve uniformity of breed ancestry among individuals consistent with selecting for high predicted breeding value (PBV) for twinning rate. Approximately $20 \%$ of the heifers and cows with the highest PBV for twinning were mated by Al to high PBV progeny proven sires. These matings resulted in high PBV young sires that were candidates for progeny testing. The remaining $80 \%$ of cows and heifers were mated by $\mathrm{Al}$ and natural service to young, unproven sires with a high PBV. Mating assignments to these young, unproven sires were made with the intent of obtaining 8 to 10 fertile daughters for ovulation rate evaluation and 10 to 12 sons per sire. Approximately $96 \%$ of heifers born twin to a bull were infertile (i.e., freemartin; Gregory et al., 1996). Young sires being progeny-tested generally produced daughters in spring and fall and progeny proven sires were used during the spring and fall.

Feeding and Management. Spring-born calves were born from early March to mid-May, and fall-born calves were born in August and September. Calves were weaned at an average of 160 to $170 \mathrm{~d}$ (early September for spring-born calves and early February for fall-born calves). Calves were creep-fed, and both

Table 2. Mean breed ancestry of calves born in 1994 and 1995 ( $\mathrm{n}=1,942)$

\begin{tabular}{lc}
\hline \hline Breed & $\begin{array}{c}\text { Percentage } \\
\text { contribution }\end{array}$ \\
\hline Holstein & 18.0 \\
Swedish Friesian & 16.1 \\
Simmental & 15.8 \\
Pinzgauer & 18.4 \\
Swedish Red and White & \\
plus Norwegian Red & 12.8 \\
Charolais & 5.3 \\
Hereford and Angus & 8.3 \\
Other breeds combined & 5.3 \\
Total & 100 \\
\hline
\end{tabular}


sexes were fed a growing diet containing $2.63 \mathrm{Mcal}$ of $\mathrm{ME} / \mathrm{kg} \mathrm{DM}$ and $14.4 \% \mathrm{CP}$ from weaning to an average age of $200 \mathrm{~d}$. At an average age of $200 \mathrm{~d}$, candidate males for progeny testing were identified and fed a diet of $2.69 \mathrm{Mcal}$ of $\mathrm{ME} / \mathrm{kg}$ of DM and $12.88 \% \mathrm{CP}$ for $140 \mathrm{~d}$, at which time final decisions were made on young sires to be retained for progeny testing. Approximately 150 units of semen were collected and frozen on all selected young sires before progeny test matings.

From weaning to $200 \mathrm{~d}$, heifers were fed a diet of $2.63 \mathrm{Mcal}$ of $\mathrm{ME} / \mathrm{kg} \mathrm{DM}$ and $14.4 \% \mathrm{CP}$; from 200 to $368 \mathrm{~d}$ heifers were fed a diet of $2.24 \mathrm{Mcal}$ of $\mathrm{ME} / \mathrm{kg}$ DM and $12.3 \%$ CP; and from 368 to 568 d heifers were fed a diet of $2.18 \mathrm{Mcal}$ of $\mathrm{ME} / \mathrm{kg} \mathrm{DM}$ and $11.7 \% \mathrm{CP}$.

Ovulation rate was determined in puberal heifers by rectal palpation of corpora lutea starting at an average age of $12 \mathrm{mo}$ and continued for eight estrous cycles (Echternkamp et al., 1990). Females were mated to produce their first calves at an average age of $2.5 \mathrm{yr}$. Generally, spring-born heifers produced their first calf in the fall and fall-born heifers produced their first calf in the spring. Scrotal circumference was measured on males developed as candidates for progeny testing at an average age of $383 d$ when final decisions were made on males to be progeny-tested.

F or greater detail on protocols for this experiment, see Echternkamp et al. (1990) and Gregory et al. (1990a,b).
Analysis of Data. Traits analyzed were ovulation rate, twinning rate as a trait of the dam, scrotal circumference of intact males, and weights of females taken at birth, $374 \mathrm{~d}, 566 \mathrm{~d}$, and $4 \mathrm{yr}$ of age. Fixed effects for individual ovulation rate were year-season birth group ( $n=20$, fall 1984 through spring 1994), age at observation (i.e., 12 to $13 \mathrm{mo}, 14$ to $15 \mathrm{mo}, 16$ to $17 \mathrm{mo}$, and $\geq 18 \mathrm{mo}$ ), and calendar month of ovulation (i.e., 1 through 12). In addition, the first ovulation rate and means of the first two through eight ovulation rates were analyzed with birth yearseason as a fixed effect. Age and month of observation for each of one through the mean of eight estrous cycles were similar for animals in each birth yearseason subclass. Fixed effects for twinning rate were year of calving ( $n=12$ ), season of calving (spring or fall), and age at calving (i.e., 2.5, 3.5, 4.5, 2 5.5). Fixed effects for scrotal circumference were age of dam, year of birth, season of birth, type of birth, with age at measurement as a covariate. Fixed effects for weight traits were type of birth, year of birth, age of dam, season of birth, with age as a covariate. For 4-yr-old weight, fixed effects were year of calving, season of calving, type of birth at calving, period of three weighings (i.e., precalving, prebreeding, and pregnancy diagnosis), and the cow's type of birth.

An animal model was used to describe the random, direct genetic effects for all traits. An uncorrelated animal effect was included to account for repeated

Table 3. Frequency distribution of multiple ovulations in puberal females ${ }^{a}$

\begin{tabular}{|c|c|c|c|c|}
\hline \multirow[b]{2}{*}{$\begin{array}{l}\text { Mean } \\
\text { ovulation } \\
\text { rate }\end{array}$} & \multirow[b]{2}{*}{$\begin{array}{c}\text { No. of } \\
\text { females }\end{array}$} & \multicolumn{3}{|c|}{ Summary } \\
\hline & & $\begin{array}{l}\text { Mean } \\
\text { ovulation } \\
\text { rate }\end{array}$ & $\begin{array}{c}\text { No. of } \\
\text { females }\end{array}$ & $\begin{array}{c}\text { Percentage } \\
\text { of total }\end{array}$ \\
\hline 1.00 & 1,208 & 1.00 & 1,208 & 42.4 \\
\hline 1.12 & 625 & & & \\
\hline 1.14 & 82 & & & \\
\hline 1.17 & 26 & & & \\
\hline 1.20 & 8 & $1.12-1.20$ & 741 & 26.0 \\
\hline 1.25 & 376 & & & \\
\hline 1.28 & 47 & & & \\
\hline 1.33 & 20 & & & \\
\hline 1.38 & 192 & & & \\
\hline 1.40 & 2 & & & \\
\hline 1.43 & 21 & $1.25-1.43$ & 658 & 23.1 \\
\hline 1.50 & 127 & & & \\
\hline 1.57 & 20 & & & \\
\hline 1.60 & 1 & & & \\
\hline 1.62 & 57 & & & \\
\hline 1.67 & 4 & & & \\
\hline 1.71 & 4 & $1.50-1.71$ & 213 & 7.5 \\
\hline 1.75 & 15 & & & \\
\hline 1.80 & 1 & & & \\
\hline 1.86 & 1 & & & \\
\hline 1.88 & 8 & & & \\
\hline 2.00 & 4 & $1.75-2.00$ & 29 & 1.0 \\
\hline
\end{tabular}


Table 4. Distribution of cows by number of parturitions and mean twinning rate ${ }^{\mathrm{a}}$

\begin{tabular}{lcc}
\hline \hline $\begin{array}{l}\text { No. of } \\
\text { parturitions }\end{array}$ & $\begin{array}{c}\text { No. of } \\
\text { cows }\end{array}$ & $\begin{array}{c}\text { Mean twinning rate } \\
\text { (calves per } \\
\text { parturition) }\end{array}$ \\
\hline 1 & 529 & 1.19 \\
2 & 472 & 1.19 \\
3 & 383 & 1.25 \\
4 & 288 & 1.21 \\
5 & 214 & 1.21 \\
6 & 136 & 1.21 \\
7 & 67 & 1.24 \\
8 & 18 & 1.33 \\
9 & 5 & 1.27 \\
10 & 1 & 1.10 \\
Overall & 2,113 & 1.22 \\
\hline
\end{tabular}

${ }^{\mathrm{a}} \mathrm{F}$ or females calving from 1984 through 1995.

measurements of ovulation rate, twinning rate, and 4-yr-old weight. A maternal effect was included for birth weight and assumed to be uncorrelated with the direct genetic effect. This assumption was based on a nonsignificant estimate of the covariance and a small value of maternal genetic variance for birth weight in another study (Bennett and Gregory, 1996), and the increased standard error of the direct genetic effect estimate when the covariance is simultaneously estimated (Meyer, 1992). An uncorrelated maternal effect was included to account for multiple observations of twinning rate from the same cow. Uncorrelated animal effects were included for ovulation rate and 4-yr-old weight because multiple observations of each of these traits were made on each animal.

Data were analyzed using an animal model, derivative-free MTDFREML program (Boldman et al., 1993). Most correlations between traits were estimated with pair-wise analyses. The analysis of ovulation rate and twinning rate estimated correlations between genetic effects and between uncorrelated animal effects for the two traits but not between residual effects because any ovulation rate measurement was not paired with any particular twinning observation. Correlations between scrotal circumference and either ovulation rate or twinning rate were estimated assuming no residual correlation between scrotal circumference measured in males and reproductive traits measured in females. Correlations between the four weights (birth, 374-d, 566-d, and 4-yr-old) and either ovulation or twinning rate were estimated assuming an uncorrelated animal effect for each weight and no correlation of residuals. Even though these three weights were measured only once, an uncorrelated animal effect was added to account for within-animal correlations between traits, but ignoring variation among repeated measurements for ovulation rate and twinning rate. The residual variance reported is the sum of estimated residual and animal effects. Correlations among the four weight traits were estimated in a single analysis including uncorrelated animal effects for the three weights, each measured once, as well as an uncorrelated animal effect for 4-yr-old weight, which was measured three times. The residual variance reported is the sum of estimated animal and residual effect variances. The residual correlations reported are the covariances of animal effects divided by the appropriate residual standard deviations.

Genetic groups (Quaas and Pollak, 1981; Westell et al., 1988) were used to account for selection before records used in the analysis. Some analyses were conducted both with and without genetic groups.

\section{Results and Discussion}

\section{Genetic Parameters}

Ovulation and Twinning Rate. Measurements of ovulation rate on 2,849 heifers with 21,418 estrous cycles born from fall of 1984 through spring of 1994 were included in the analyses (Table 3). Ovulation rates recorded at an age of less than $12 \mathrm{mo}$ and greater than eight estrous cycles were deleted from the data set. Mean ovulation rate was 1.16 per estrous cycle. Ovulation rate increased from a mean of 1.11 per estrous cycle for females born in the fall of 1984 to a mean of 1.26 per estrous cycle for females born in 1994. Mean ovulation rate increased from 1.12 at 12 to $13 \mathrm{mo}$ to 1.19 at $18 \mathrm{mo}$. Mean ovulation rate ranged from a low of 1.13 in March and April to a high of 1.17 in November.

Twinning rate data on 2,113 cows with 6,328 parturitions from 1984 through 1995 were included in the analyses (Table 4). Mean twinning rate was 1.22 calves per parturition and ranged from 1.04 in 1984 to 1.31 in 1995. Twinning rate was 1.202 calves per parturition for spring-born calves and 1.235 for fallborn calves. Twinning rate averaged 1.18 calves per parturition for 2.5-yr-old females and 1.24 for females $\geq 3 \mathrm{yr}$ old.

Table 5. Estimates of heritability of means of ovulation rate in puberal heifers with different number of observations ${ }^{a}$

\begin{tabular}{lccc}
\hline \hline & & \multicolumn{2}{c}{ Genetic groups in model } \\
\cline { 3 - 4 } No. of & No. of & Yes & No \\
\hline 1 & 2,849 & .11 & .11 \\
2 & 2,823 & .16 & .17 \\
3 & 2,803 & .20 & .21 \\
4 & 2,768 & .24 & .25 \\
5 & 2,706 & .28 & .28 \\
6 & 2,669 & .35 & .36 \\
7 & 2,569 & .37 & .38 \\
8 & 2,231 & .38 & .38 \\
\hline
\end{tabular}

${ }^{\mathrm{a}} \mathrm{E}$ stimated from the mean of the first, the first and second, ...., and all eight estrous cycles. 
Heritability estimates $\left(\mathrm{h}^{2}\right)$ of ovulation rate for different number of estrous cycles (i.e., for one through the mean of eight estrous cycles) with genetic groups and without genetic groups included in the model are presented in Table 5 . The $\mathrm{h}^{2}$ estimates of the mean of two through the mean of eight estrous cycles are in close agreement with estimates computed using the repeated records formula of Lush (1945); $h_{\bar{X}} \frac{2}{}$ $=\left(n h^{2}\right) /[1+(n-1) r]$ where $n=$ number of records and $r=$ repeatability using the estimates for $h^{2}$ and $r$ $\left(r=h^{2}+c^{2}\right)$ from all records (Table 6). These estimates, with and without genetic groups in the model, show important increases in $\mathrm{h}^{2}$ up to the mean of six estrous cycles but only limited increases in $h^{2}$ for more than six estrous cycles. Including genetic groups in the model had little effect on estimates of $h^{2}$ for ovulation rate.

Estimates of $\mathrm{h}^{2}$ for ovulation and twinning rate were .10 and .09 , respectively, with genetic groups in the model, and .10 for ovulation and twinning rates without genetic groups in the model (Table 6). With genetic groups in the model, the estimates of the proportion of the total variance due to permanent environmental effects $\left(c^{2}\right)$ was .04 for ovulation rate and .03 for twinning rate. The $r_{g}$ was .75 between ovulation and twinning rate with genetic groups and .76 without genetic groups in the model (Table 6).
Including genetic groups in the model had little effect on estimates of $h^{2}$ or $r_{g}$ involving ovulation rate and twinning rate. These estimates of $h^{2}$ are higher than those reported by Van Vleck and Gregory (1996) of .07 for ovulation rate and .03 for twinning rate with genetic groups in the model. Van Vleck and Gregory (1996) reported an $r_{g}$ of 1.00 between ovulation and twinning rate with genetic groups and .76 without genetic groups in the model. The difference in the data sets is that in the current study twinning rate data were available through 1995 and ovulation rate data were available for females born through the spring of 1994 (i.e., two additional years for ovulation and twinning rates). Also, data on twinning rate for parturitions prior to 1984 were excluded from the current analyses, whereas Van Vleck and Gregory (1996) included parturition records starting in 1982. The difference in magnitude of estimates between the two studies is likely the result of an increase in frequency of alleles affecting ovulation rate and twinning rate as a result of data from two later years included in the current study and the deletion of records for parturitions prior to 1984.

Scrotal Circumference and Ovulation and Twinning Rate. Scrotal circumference was recorded on progeny test candidate males born from spring of 1984 through fall of 1994. Mean scrotal circumference was $35.0 \mathrm{~cm}$ adjusted to a mean age of $383 \mathrm{~d}$. Scrotal circumference did not differ between spring- and fall-born males.

Table 6. Estimates of genetic and environmental parameters for ovulation rate, twinning rate, and weight traits ${ }^{a}$

\begin{tabular}{|c|c|c|c|c|c|c|c|c|}
\hline \multirow[b]{2}{*}{ Trait } & \multirow{2}{*}{$\begin{array}{c}\text { No. of } \\
\text { observations }\end{array}$} & \multirow[b]{2}{*}{$h^{2}$} & \multirow[b]{2}{*}{$c^{2}$} & \multirow[b]{2}{*}{$\mathrm{e}^{2}$} & \multicolumn{2}{|c|}{$\begin{array}{l}\text { Ovulation } \\
\text { rate }\end{array}$} & \multicolumn{2}{|c|}{$\begin{array}{l}\text { Twinning } \\
\text { rate }\end{array}$} \\
\hline & & & & & $r_{g}$ & $r_{c}$ & $r_{g}$ & $r_{c}$ \\
\hline \multicolumn{9}{|l|}{ Ovulation rate } \\
\hline With genetic groups & 21,418 & .10 & .04 & .86 & & & .75 & .59 \\
\hline Without genetic groups & & .10 & .04 & .86 & & & .76 & .56 \\
\hline \multicolumn{9}{|l|}{ Twinning rate } \\
\hline With genetic groups & 6,328 & .09 & .03 & .88 & .75 & .59 & & \\
\hline Without genetic groups & & .10 & .02 & .88 & .76 & .56 & & \\
\hline \multicolumn{9}{|l|}{ Scrotal circumference } \\
\hline With genetic groups & 565 & .25 & & .75 & .29 & & .38 & \\
\hline \multicolumn{9}{|l|}{ Birth weight } \\
\hline With genetic groups & 3,315 & & & & & & & \\
\hline (Direct) & & .42 & & $.47^{b}$ & .22 & $.12^{\mathrm{c}}$ & .24 & $.15^{\mathrm{c}}$ \\
\hline (Maternal) & & .11 & & & & & & \\
\hline \multicolumn{9}{|l|}{ 374-d weight } \\
\hline With genetic groups & 3,315 & .47 & & $.53^{b}$ & .30 & $.34^{\mathrm{c}}$ & .39 & $-.10^{c}$ \\
\hline \multicolumn{9}{|l|}{ 566-d weight } \\
\hline With genetic groups & 3,202 & .44 & & $.56^{b}$ & .15 & $.08^{\mathrm{c}}$ & .26 & $-.02^{c}$ \\
\hline \multicolumn{9}{|l|}{ 4-yr-old weight } \\
\hline With genetic groups & 2,475 & .54 & .21 & .25 & .24 & .40 & .31 & .11 \\
\hline
\end{tabular}

aAnalysis of scrotal circumference and weight traits were conducted pair-wise with ovulation rate and twinning rate.

${ }^{b}$ Estimates of $c^{2}$ and $e^{2}$ were combined into a single estimate of $\mathrm{e}^{2}$ because there were no repeated measurements of this trait.

${ }^{\mathrm{C}}$ Estimates of nongenetic correlation between repeated measurements of ovulation rate and twinning rate with a single measurement of weight. 
The estimate of $h^{2}$ for scrotal circumference with genetic groups in the model and of $r_{g}$ of scrotal circumference with ovulation and twinning rates are given in Table 6 . The $\mathrm{h}^{2}$ for scrotal circumference (.25) was lower than reported by Gregory et al. (1995b). The $r_{g}$ of scrotal circumference with ovulation and twinning rates (.29 and .38) are likely of a magnitude sufficient to be considered in selecting for ovulation and twinning rate. The basis for these analyses relating to scrotal circumference is that scrotal circumference is associated with age at puberty in females, which seems to be associated with subsequent reproductive performance (Brinks et al., 1978).

Birth Weight and Ovulation and Twinning Rate. Birth weights recorded from 1982 through 1994 were included in this study. The rationale for estimating the $r_{g}$ between weight traits and ovulation and twinning rates is that no breed of cattle that is small in size produces twins at a high frequency (Rutledge, 1975). Because of the high level of dystocia in this population (Gregory et al., 1996), consideration of birth weight to reduce dystocia is desirable. Thus, it is necessary to know the genetic relationship between growth traits and ovulation rate and twinning rate. This was a primary objective of the study. Mean birth weight was $42.8 \mathrm{~kg}$; singles averaged $44.0 \mathrm{~kg}$ and twins averaged $36.4 \mathrm{~kg}$. Fall-born calves weighed 816 $\mathrm{g}$ more than spring-born calves. Calves with 2.5 -yr-old dams weighed $2.4 \mathrm{~kg}$ less than calves with 3 -yr-old dams and $2.9 \mathrm{~kg}$ less than calves with dams $\geq$ $4 \mathrm{yr}$ old.

Estimates of $h^{2}$ for birth weight and of $r_{g}$ of birth weight with ovulation and twinning rate with genetic groups in the model are presented in Table 6 . The $h^{2}$ of birth weight (.42 direct and .11 maternal) are in close agreement with a report for females by Gregory et al. (1995a). The estimates of $r_{g}$ of .22 and .24 for birth weight with ovulation and twinning rate, respectively, indicate a genetic antagonism between low birth weight with high ovulation rate and twinning rate that will require some compromise in selecting simultaneously for twinning rate and reduced birth weight.

374-Day Weight and Ovulation and Twinning Rate. Mean heifer weight adjusted to $374 \mathrm{~d}$ was $364 \mathrm{~kg}$. Birth years included were 1982 through 1994. Fallborn heifers were $23.2 \mathrm{~kg}$ heavier than spring-born heifers at $374 \mathrm{~d}$. Heifers born as singles were $14.2 \mathrm{~kg}$ heavier at $374 \mathrm{~d}$ than heifers born as twins. Age of dam did not affect adjusted 374-d weight.

Palpation for determination of ovulation rate was started at an average age of $374 \mathrm{~d}$. Estimates of $\mathrm{h}^{2}$ for 374-d weight and of $r_{g}$ of 374-d weight with ovulation and twinning rate with genetic groups in the model are presented in Table 6 . Direct and maternal $h^{2}$ estimates of 374-d weight were included in an initial analysis; the maternal $\mathrm{h}^{2}$ estimate was 0 and was deleted and the analysis was run to estimate only direct $h^{2}$. The estimate of $h^{2}$ for 374-d weight was .47 and is in close agreement with a report for females of Gregory et al. (1995a). The $r_{g}$ of .30 and .39 between 374-d weight and ovulation and twinning rate, respectively, suggest a genetic antagonism between fecundity and growth in cattle of a magnitude sufficient to require some compromise when the selection goal is increased twinning rate with no change in growth and size.

566-Day Weight and Ovulation and Twinning Rate. Mean heifer weight adjusted to $566 \mathrm{~d}$ was $455 \mathrm{~kg}$. Birth years included were 1982 through 1994. Fallborn heifers weighed $16.1 \mathrm{~kg}$ more than spring-born heifers at $566 \mathrm{~d}$. Heifers born and reared as singles were $9.4 \mathrm{~kg}$ heavier than heifers born as twins. Age of dam did not affect 566-d weight.

These weights were recorded subsequent to ovulation rate determination. Estimates of $h^{2}$ for 566-d weight and of $r_{g}$ of 566-d weight with ovulation and twinning rate with genetic groups in the model are presented in Table 6 . The estimate of $h^{2}$ for 566-d weight was .44 and is in close agreement with a report for females of Gregory et al. (1995a). The $r_{g}$ of .15 and .26 between 566-d weight and ovulation and twinning rates, respectively, were lower than the $r_{g}$ of ovulation rate and twinning rate with 374-d weight.

Four-Year-Old Weight and Ovulation and Twinning Rate. Four-year-old weights were recorded before calving, before breeding, and when palpated for pregnancy diagnosis in spring- and fall-calving cows. Cows that did not wean a calf were deleted from the data set for that year. Four-year-old weight data recorded from 1986 through 1995 were included in the analysis. Mean cow weight for the three weights recorded at $4 \mathrm{yr}$ was $656 \mathrm{~kg}$. Cow weights did not differ between spring- and fall-calving cows. Cows calving twins weighed $19 \mathrm{~kg}$ more for the mean of the three weights than cows calving singles. Cows weighed $52 \mathrm{~kg}$ more before calving than before breeding and $57 \mathrm{~kg}$ more before calving than when palpated for pregnancy diagnosis. Cows born and reared as singles weighed an average of $29 \mathrm{~kg}$ more than cows born as twins.

Estimate of $\mathrm{h}^{2}$ for $4-\mathrm{yr}$-old weight was .54 with genetic groups in the model. Estimates of $r_{g}$ between 4-yr-old weight and ovulation rate and twinning rate, respectively, were .24 and .31 . The estimate of $h^{2}$ for 4-yr-old weight is in general agreement with Gregory et al. (1995a). The estimate of fraction of variance due to permanent environmental effects $\left(c^{2}\right)$ for the three weights (i.e., before calving, before breeding, and pregnancy diagnosis) taken at $4 \mathrm{yr}$ of age was .21. Thus, the estimate of repeatability of the three weights taken at $4 \mathrm{yr}$ was .75.

The estimates of $h^{2}$ presented for scrotal circumference, birth, 374-d, 566-d, and 4-yr-old weights are the means of the estimates when the weight trait was run 
Table 7. Estimates of genetic and environmental ${ }^{\mathrm{b}}$ parameters for weight traits with genetic groups ${ }^{c}$

\begin{tabular}{|c|c|c|c|c|c|c|c|c|}
\hline Trait & $\begin{array}{c}\text { No. of } \\
\text { observations }\end{array}$ & $h^{2}$ & $c^{2}$ & $\mathrm{e}^{2}$ & $\begin{array}{c}\text { Birth } \\
\text { wt }\end{array}$ & $\begin{array}{c}\text { 374-d } \\
\text { wt }\end{array}$ & $\begin{array}{c}566-d \\
\text { wt }\end{array}$ & $\begin{array}{c}\text { 4-yr-old } \\
\text { wt }\end{array}$ \\
\hline $\begin{array}{l}\text { Birth wt } \\
\text { (Direct) } \\
\text { (Maternal) }\end{array}$ & 3,315 & $\begin{array}{l}.51 \\
.06\end{array}$ & & .42 & & .17 & .06 & -.08 \\
\hline 374-d wt & 3,315 & .56 & & .44 & .68 & & .54 & -.02 \\
\hline 566-d wt & 3,202 & .54 & & .46 & .65 & .82 & & .21 \\
\hline 4-yr-old wt & 2,475 & .70 & .07 & .23 & .73 & .84 & .88 & \\
\hline
\end{tabular}

${ }^{\mathrm{a}}$ Genetic correlations below diagonal.

bEnvironmental correlations above diagonal in boldface type.

'All weights were included in same analysis.

separately in pair-wise analyses with ovulation rate and with twinning rate. The maximum difference observed between the two estimates was .03 .

Weight Traits. Estimates of $\mathrm{h}^{2}$ and $\mathrm{r}_{\mathrm{g}}$ for weight traits with genetic groups in the model are presented in Table 7 when weight traits were analyzed in one analysis in a four-trait model.

Estimates of $\mathrm{h}^{2}$ for weight traits were greater, except for maternal birth weight, than when weight traits were estimated with ovulation rate and with twinning rate in pair-wise analyses (Table 6). The same data set for weight traits was included in all analyses. An explanation for the difference in estimates of $h^{2}$ for weight traits in the separate analyses is not apparent. Estimates of $h^{2}$ (direct) for weight traits in this analysis ranged from .51 to .70 and estimates of $r_{g}$ among weight traits ranged from .65 to .88. Environmental correlations among weight traits were small, except between 374-d and 566-d weight (Table 7). These estimates of $h^{2}$ and $r_{g}$ for weight traits are in general agreement with the report of Bennett and Gregory (1996).

\section{Phenotypic and Genetic Trends}

The genetic groups contributing to the foundation population and solutions for twinning rate and ovulation rate are presented in Table 8 . As indicated by Table 8, the genetic differences among sources in ovulation and twinning rate were large. This is expected because sires in genetic groups 1 and 7 were identified based on twinning rate of their daughters.

Twinning Rate. Twinning rates for parturitions in spring of 1996 were included in this part of the study, whereas data for parameter estimates extended only through fall of 1995 parturitions. Twinning rate data for spring 1996 were available when this part of the study was conducted. The PBV for ovulation and twinning rate were estimated using the genetic parameters presented in Table 6. Phenotypic and genetic trends for twinning rate are presented in Table 9 by year of calving of females from 1984 through spring calving of 1996, and in Table 10 by year of birth of female from 1981 through fall of 1993.
Estimated genetic trends are reflected by PBV adjusted for each group in each year by a constant equal to the difference between phenotypic mean and PBV for the initial year of calving (Table 9) or initial year of birth (Table 10). This adjustment was made to achieve equality of initial values for phenotypic means and PBV. When expressed on the basis of year of calving (Table 9), the phenotypic change in twinning rate over the 12-yr period exceeded the estimate of genetic change (.29 vs .22). The phenotypic change was .027 calves per parturition per year in twinning rate, whereas the estimated genetic change was .019 calves per parturition per year in twinning rate. Regressions for phenotypic mean twinning rate and adjusted PBV on year of calving are presented in Table 9 and on year of birth are presented in Table 10.

When expressed on the basis of year of birth (Table $10)$, the phenotypic change in twinning rate over the 12 -yr period was .22 calves per parturition compared with .26 calves per parturition for estimated genetic change. For both methods of expression (i.e., year of calving or year of birth) the rate of increase in phenotypic mean and estimated genetic mean tended to be greater in the later six or seven years of the experiment. Several factors likely account for this result: 1) greater impact of progeny proven sires

Table 8. Solutions for twinning rate and ovulation rate for genetic groups contributing to the foundation population

\begin{tabular}{|c|c|c|}
\hline \multirow[b]{2}{*}{$\begin{array}{l}\text { Genetic } \\
\text { group }\end{array}$} & \multicolumn{2}{|c|}{ Solution } \\
\hline & $\begin{array}{l}\text { Twinning } \\
\text { rate }\end{array}$ & $\begin{array}{c}\text { Ovulation } \\
\text { rate }\end{array}$ \\
\hline Scandinavian sires & .1752 & .0847 \\
\hline MARC populations & .0022 & -.0257 \\
\hline Holsteins in Period $1^{a}$ & .0000 & .0000 \\
\hline Holsteins in Period $2^{\mathrm{a}}$ & .0276 & -.0170 \\
\hline Other breeds in Period $1^{a}$ & -.1137 & -.1028 \\
\hline Other breeds in Period $2^{\mathrm{a}}$ & .0112 & -.0662 \\
\hline MARC progeny proven sires & .3018 & .0384 \\
\hline
\end{tabular}

aperiod 1 was acquisition prior to 1980 and Period 2 was acquisition in either 1981 or 1982. Different criteria were used between Period 1 and Period 2. 
Table 9. Phenotypic means and mean adjusted predicted breeding values (PBV) by year of calving for twinning rate for females born in the project and their sires and dams; PBV were estimated from a genetic model including genetic groups and parameters estimated jointly

\begin{tabular}{lccccc}
\hline \hline $\begin{array}{l}\text { Year of } \\
\text { calving }\end{array}$ & $\begin{array}{c}\text { No. of } \\
\text { parturitions }\end{array}$ & $\begin{array}{c}\text { Phenotypic } \\
\text { mean } \\
\text { twinning rate }\end{array}$ & $\begin{array}{c}\text { Adjusted } \\
\text { mean PBV } \\
\text { of females }^{\mathrm{a}}\end{array}$ & $\begin{array}{c}\text { Adjusted } \\
\text { mean PBV } \\
\text { of sires }^{\mathrm{a}}\end{array}$ & $\begin{array}{c}\text { Adjusted } \\
\text { mean PBV } \\
\text { of dams }^{\mathrm{a}}\end{array}$ \\
\hline 1984 & 77 & 1.04 & 1.04 & 1.05 & 1.03 \\
1985 & 194 & 1.06 & 1.05 & 1.06 & 1.05 \\
1986 & 279 & 1.08 & 1.06 & 1.07 & 1.06 \\
1987 & 423 & 1.09 & 1.08 & 1.09 & 1.07 \\
1988 & 425 & 1.12 & 1.09 & 1.12 & 1.07 \\
1989 & 544 & 1.15 & 1.11 & 1.14 & 1.08 \\
1990 & 646 & 1.20 & 1.13 & 1.15 & 1.09 \\
1991 & 755 & 1.23 & 1.14 & 1.17 & 1.10 \\
1992 & 790 & 1.24 & 1.17 & 1.20 & 1.12 \\
1993 & 734 & 1.28 & 1.21 & 1.25 & 1.14 \\
1994 & 740 & 1.34 & 1.23 & 1.27 & 1.16 \\
1995 & 721 & 1.31 & 1.25 & 1.28 & 1.19 \\
1996 & 358 & 1.33 & 1.26 & 1.30 & 1.20 \\
Mean & 6,686 & 1.22 & 1.16 & 1.19 & 1.12 \\
Regression on year & & .027 & .019 & .022 & .013 \\
\hline
\end{tabular}

${ }^{\mathrm{a} A}$ constant value of -.0546 was added to PBV for all groups in all years to reflect the difference between the phenotypic mean for twinning rate and PBV for females calving in 1984.

including introduced sires and those identified in the experiment based on ovulation rate of daughters; 2) increased genetic variation in the population as the experiment progressed reflecting increased frequency of twinning; and 3) improved procedures for estimating breeding value for twinning rate using a multipletrait repeated records animal model starting in 1990 (Van Vleck et al., 1991b). Overall, agreement is reasonably good between the phenotypic means and the estimated genetic means when expressed on year of calving and on year of birth bases. When expressed on a year of calving basis, all females were included regardless of their year of birth, and when expressed on a year of birth basis all females born in a given year were included regardless of the year(s) they calved.

Estimated genetic means for twinning rate for sires increased by .25 calves per parturition and for dams

Table 10. Phenotypic means and mean adjusted predicted breeding values (PBV) by year of birth for twinning rate for females born in the project and their sires and dams; PBV were estimated from a genetic model including genetic groups and parameters estimated jointly

\begin{tabular}{lccccc}
\hline \hline $\begin{array}{l}\text { Year of } \\
\text { birth }\end{array}$ & $\begin{array}{c}\text { No. } \\
\text { parturitions }\end{array}$ & $\begin{array}{c}\text { Phenotypic } \\
\text { mean } \\
\text { twinning rate }\end{array}$ & $\begin{array}{c}\text { Adjusted } \\
\text { mean PBV } \\
\text { of females }^{\mathrm{a}}\end{array}$ & $\begin{array}{c}\text { Adjusted } \\
\text { mean PBV } \\
\text { of sires }^{\mathrm{a}}\end{array}$ & $\begin{array}{c}\text { Adjusted } \\
\text { mean PBV } \\
\text { of dams }^{\mathrm{a}}\end{array}$ \\
\hline 1981 & 81 & 1.07 & 1.07 & 1.10 & 1.06 \\
1982 & 288 & 1.12 & 1.12 & 1.12 & 1.12 \\
1983 & 522 & 1.10 & 1.13 & 1.14 & 1.13 \\
1984 & 678 & 1.13 & 1.15 & 1.14 & 1.15 \\
1985 & 844 & 1.16 & 1.18 & 1.21 & 1.13 \\
1986 & 611 & 1.17 & 1.20 & 1.27 & 1.13 \\
1987 & 721 & 1.28 & 1.24 & 1.28 & 1.17 \\
1988 & 625 & 1.33 & 1.27 & 1.28 & 1.21 \\
1989 & 634 & 1.23 & 1.25 & 1.27 & 1.21 \\
1990 & 541 & 1.32 & 1.30 & 1.35 & 1.22 \\
1991 & 522 & 1.33 & 1.30 & 1.35 & 1.23 \\
1992 & 369 & 1.30 & 1.30 & 1.33 & 1.26 \\
1993 & 250 & 1.29 & 1.33 & 1.37 & 1.29 \\
Regression & & .022 & .021 & .024 & .016 \\
\hline
\end{tabular}

${ }^{a} \mathrm{~A}$ constant value of .0061 was added to PBV for all groups in all years to reflect the difference between the phenotypic mean for twinning rate and PBV for 1981 birth year. 
Table 11. Phenotypic means and mean adjusted predicted breeding values (PBV) for ovulation rate of puberal heifers and their sires and dams; PBV were estimated from a genetic model including genetic

groups and parameters estimated jointly

\begin{tabular}{lccccc}
\hline \hline $\begin{array}{l}\text { Year of } \\
\text { birth }\end{array}$ & $\begin{array}{c}\text { No. of } \\
\text { estrous } \\
\text { cycles }\end{array}$ & $\begin{array}{c}\text { Phenotypic } \\
\text { mean } \\
\text { ovulation rate }\end{array}$ & $\begin{array}{c}\text { Adjusted } \\
\text { mean PBV } \\
\text { of females }\end{array}$ & $\begin{array}{c}\text { Adjusted } \\
\text { mean PBV } \\
\text { of sires }^{\text {a }}\end{array}$ & $\begin{array}{c}\text { Adjusted } \\
\text { mean PBV } \\
\text { of }^{\text {dams }}{ }^{\mathrm{a}}\end{array}$ \\
\hline 1984 & 268 & 1.11 & 1.11 & 1.11 & 1.12 \\
1985 & 978 & 1.11 & 1.13 & 1.16 & 1.11 \\
1986 & 857 & 1.11 & 1.14 & 1.16 & 1.11 \\
1987 & 2,535 & 1.15 & 1.15 & 1.17 & 1.12 \\
1988 & 2,537 & 1.16 & 1.17 & 1.19 & 1.14 \\
1989 & 2,535 & 1.16 & 1.17 & 1.20 & 1.15 \\
1990 & 2,440 & 1.16 & 1.20 & 1.25 & 1.16 \\
1991 & 2,650 & 1.14 & 1.21 & 1.25 & 1.17 \\
1992 & 2,536 & 1.17 & 1.22 & 1.24 & 1.20 \\
1993 & 2,686 & 1.18 & 1.26 & 1.29 & 1.23 \\
1994 & 2,165 & 1.26 & 1.29 & 1.33 & 1.24 \\
Mean & 22,187 & 1.17 & 1.20 & 1.23 & 1.17 \\
Regression on year & & .011 & .016 & .019 & .013 \\
\hline
\end{tabular}

${ }^{\mathrm{a}} \mathrm{A}$ constant of .0515 was added to PBV for all groups in all years to reflect the difference between the phenotypic mean for ovulation rate and PBV for puberal females born in 1984.

.17 calves per parturition over the 12-yr period when expressed by year of calving (Table 9). Much of this difference between sires and dams in estimated genetic value for twinning occurred starting in 1988 after use of progeny proven sires was having an impact. Estimated genetic means for twinning rate for sires increased by .27 calves per parturition and for dams by .23 calves per parturition over the 12-yr period when expressed by year of birth (Table 10). As indicated by Table 9 the experimental population was increased to 750 calving cows per year in the 1991 calving year. Thus, all normal females were retained for breeding until the 1988 birth year. Starting with the 1988 birth year, approximately $25 \%$ of yearling females were removed from the experiment based primarily on PBV after palpation for ovulation rate. Because of the high rate of estimated genetic change, selection among females based primarily on PBV for twinning rate favored the retention of a high percentage of yearling females and the removal of older females after the experimental population reached 750 calving females. The estimated genetic means for cows by year of calving and year of birth approximate the mean estimated genetic values of their sires and dams (Tables 9 and 10).

Comparison of sire and dam mean values shows that more of the progress results from sire selection. Because information is available on ovulation rate of females before their entry into the breeding herd at $1.5 \mathrm{yr}$ and ovulation rate information is not available on daughters of sires until sires are 4.5 to $5 \mathrm{yr}$ old, the difference between sires and dams in genetic value may be less over a short period than would be expected for non-sex-limited traits. Thus, there is a difference of approximately $3 \mathrm{yr}$ between when ovulation rate data are available on females and when ovulation rate data are available on daughters of sires. Over a short period, this difference may be sufficient to more than offset the increased precision with which PBV are determined in sires relative to dams and the greater selection intensity of sires. The difference in estimated genetic value for twinning rate between sires and dams is similar to that reported for a more limited ( $2.5 \mathrm{yr}$ less) data set reported by Van Vleck and Gregory (1996).

Ovulation Rate. Ovulation rates for females born in the fall of 1984 through the fall of 1994 were included in this part of the study, whereas results presented for parameter estimates extended only through females born in spring of 1994. Ovulation rate data for females born in fall of 1994 were available when data were analyzed for this part of the study but were not available when genetic parameters involving ovulation rate were estimated. Phenotypic and genetic trends for ovulation rate in puberal heifers are presented in Table 11 for fall 1984 through fall 1994 birth groups. Estimated genetic trends are reflected by PBV adjusted for each group in each year by a constant equal to the difference between phenotypic mean and PBV for the 1984 fall birth group when ovulation rate determinations were started. This adjustment was made to achieve equality of initial values for phenotypic means and PBV. The phenotypic change in ovulation rate over the $11 \mathrm{yr}$ was .15 per estrous cycle, whereas the estimated genetic change was .18 per estrous cycle. Regressions for phenotypic mean ovulation rate and adjusted PBV on year of birth are presented in Table 11 . The changes in estimated genetic means were more consistent on a yearly basis than changes in phenotypic means. From 1987 through 1991, phenotypic means did not seem to change. The estimated genetic means for ovulation 
and twinning rates did change during this period (Tables 10 and 11). However, phenotypic means for twinning rate did not show great change for females born since 1987 (Table 10). The difference between ovulation rate in puberal heifers and twinning rate in cows is believed to result primarily from age effects on ovulation rate. Echternkamp et al. (1990) reported small $(P>.05)$ differences in embryonal and fetal survival between single and double ovulating cows. Ovulation rate increased by .0129 per month from 12 to 18 mo during the period that ovulation rate was evaluated. As was observed for twinning rate, the estimated genetic mean for ovulation rate is in reasonably close agreement with the estimated genetic mean of sires and dams, with sires having a greater impact than dams on estimated genetic change.

\section{Implications}

A twinning technology has the potential to improve efficiency of beef production under intensive production systems. Ovulation rate in puberal heifers is an effective indirect selection criterion to increase twinning rate because of the high genetic correlation between ovulation rate and twinning rate (.75). Repeated observations of ovulation rate for a mean of six estrous cycles results in a trait of intermediate heritability (.35). Positive genetic correlations between weight traits and ovulation and twinning rate suggest some compromise when the selection goal is increased twinning rate with no increase in growth and size.

\section{Literature Cited}

Bennett, G. L., and K. E. Gregory. 1996. Genetic (co)variances among birth weight, 200-day weight, and postweaning gain in composites and parental breeds of beef cattle. J. Anim. Sci. 74: 2598.

Boldman, K. G., L. A. Kriese, L. D. Van Vleck, and S. D. Kachman. 1993. A Manual for Use of MTDFREML. A set of programs to obtain estimates of variances and covariances [Draft]. ARS, USDA, Clay Center, NE.

Brinks, J. S., M. J . Mcl nerney, and P. J . Chenoweth. 1978. Relationship of age at puberty in heifers to reproductive traits in young bulls. Proc. West. Sect. Am. Soc. Anim. Sci. 29:28.
Echternkamp, S. E., K. E. Gregory, G. E. Dickerson, L. V. Cundiff, R. M. Koch, and L. D. Van Vleck. 1990. Twinning in cattle: II. Genetic and environmental effects on ovulation rate in puberal heifers and postpartum cows and the effects of ovulation rate on embryonic survival. J. Anim. Sci. 68:1877.

Gregory, K. E., L. V. Cundiff, and R. M. Koch. 1995a. Genetic and phenotypic (co)variances for production traits of female populations of purebred and composite beef cattle. J . Anim. Sci. 73: 2235.

Gregory, K. E., L. V. Cundiff, and R. M. Koch. 1995b. Genetic and phenotypic (co)variances for production traits of intact male populations of purebred and composite beef cattle. J . Anim. Sci. 73:2227.

Gregory, K. E., and G. E. Dickerson. 1989. Sampling, evaluation, and utilization of animal genetic resources. In: L. Knutson and A. K. Stoner (E d.) Proc. Beltsville Symp. XIII Biotic Diversity and Germplasm Preservation-Global Imperatives. p 185. Kluwer Academic Publishers, The Netherlands.

Gregory, K. E., S. E. Echternkamp, and L. V. Cundiff. 1996. Effects of twinning on dystocia, calf survival, calf growth, carcass traits, and cow productivity. J. Anim. Sci. 74:1223.

Gregory, K. E., S. E. Echternkamp, G. E. Dickerson, L. V. Cundiff, R. M. Koch, and L. D. Van Vleck. 1990a. Twinning in cattle: I. Foundation animals and genetic and environmental effects on twinning rate. J. Anim. Sci. 68:1867.

Gregory, K. E., S. E. Echternkamp, G. E. Dickerson, L. V. Cundiff, R. M. Koch, and L. D. Van Vleck. 1990b. Twinning in cattle: III. Effects of twinning on dystocia, reproductive traits, calf survival, calf growth and cow productivity. J . Anim. Sci. 68:3133.

Guerra-Martinez, P., G. E. Dickerson, G. B. Anderson, and R. D. Green. 1990. Embryo-transfer twinning and performance efficiency in beef production. J. Anim. Sci. 68:4039.

Lush, J. L. 1945. Animal Breeding Plans. Iowa State University Press, Ames. p 173.

Meyer, K. 1992. Bias and sampling covariances of estimates of variance components due to maternal effects. Genet. Sel. Evol. 24:487.

Quaas, R. L., and E. J. Pollak. 1981. Modified equations for sire models with groups. J. Dairy Sci. 64:1868.

Reid, J . T., O. D. White, R. Anrique, and A. Fortin. 1980. Nutritional energetics of livestock: Some present boundaries of knowledge and future research needs. J. Anim. Sci. 51:1393.

Rutledge, J. J. 1975. Twinning in cattle. J. Anim. Sci. 40:803.

Van Vleck, L. D., and K. E. Gregory. 1996. Genetic trend and environmental effects in a population of cattle selected for twinning. J. Anim. Sci. 74:522.

Van Vleck, L. D., K. E. Gregory, and S. E. Echternkamp. 1991a. Ovulation rate and twinning rate in cattle: Heritabilities and genetic correlation. J. Anim. Sci. 69:3213.

Van Vleck, L. D., K. E. Gregory, and S. E. Echternkamp. 1991b. Prediction of breeding values for twinning rate and ovulation rate with a multiple trait, repeated records animal model. J. Anim. Sci. 69:3959.

Westell, R. A., R. L. Quaas, and L. D. Van Vleck. 1988. Genetic groups in an animal model. 1988. J. Dairy Sci. 71:1310. 